\title{
FOUCAULT AS EDUCATOR
}

Stephen Ball

Springer. 2017. xix + pp. 88.

ISBN: 978-3-319-50302-8

\section{Reviewed by Roger Deacon}

University of KwaZulu-Natal, South Africa

deacon@ukzn.ac.za

What can we do with Foucault? We can use Foucault to reflect on education as a social and political practice; we can apply his critical methods, his genealogical testing and transgression of the limits that this very education imposes on us; and at the same time we can experiment with what might lie on the other side of these limits, by rewriting and re-enacting our selves and our very lives.

This question, and these answers, are at the heart of this short book, part of the SpringerBriefs series on key thinkers in education which aims to provide "a concise introduction" to the life and works of each such thinker and to acquaint readers with their major contributions in "a fast and easy way" (Ball 2017, i).

This book does much more than introduce, however; it broaches new ideas, issues and problems, and develops Foucault's thought further. Although it is less than 100 pages, it includes a wealth of detail and insights. It contains a helpful overall abstract as well as abstracts preceding each of the three chapters, and it incorporates email exchanges between the author and teachers, which are used to productively and creatively explore key Foucauldian concepts and methods (such as genealogy, transgression, power/ knowledge and parrhesia). The book is also an exercise in self-writing, in the personal development of the author, who readily admits to be "more concerned with style and practice than with method and argument" (Ball 2017, xiv).

Method and argument abound, nevertheless. Ball suggests that we can learn several things from Foucault: the use of paradox as an empirical and analytic device; the technique of reversal, or critically inverting and subverting traditional interpretations; the tendency to use key words in different senses with different meanings; and the use of illustration or demonstration as a technique of analysis, or showing as much as saying.

While ranging across Foucault's entire corpus, the book gives most attention to Foucault's 1970s and 1980s work, particularly Discipline and Punish (1975, in French) and also the later works on subjectivity and care for the self, such as the three volumes

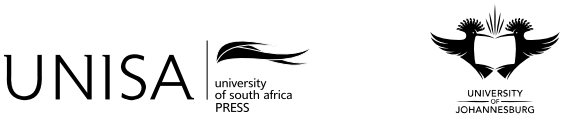


on The History of Sexuality (1976 and 1984, in French). (One exception to this is a very interesting investigation that Ball undertakes into where pedagogy might be located in relation to the emergence of "sciences" such as economics, linguistics and biology, examined by Foucault in The Order of Things [1966, in French]; undoubtedly, Ball points out, man does not just live, speak and produce but also learns.)

Foucault saw the more "child-centred" educational forms that arose during the twentieth century as possibly being even more effective "conducts of conduct" than prior disciplinary techniques which had centred on teachers, examinations and corporal punishment. The emphasis was now on developmentalism, free self-expression and the "whole child," involving "a shift to attuning pedagogy to the child (invisible) rather than the child to pedagogy (visible)" (20). In this intensification (rather than liberalisation) of power relations, "the whole child is opened up to the expert pedagogic gaze of the teacher" (21; emphasis in the original).

Although these new forms of pedagogy were not always sufficiently aligned to neoliberal needs and in recent years there has been a return to performance, measurement and examination, Ball argues that the move from progressive to neoliberal pedagogy was not a clean break. Here and throughout the book Ball modifies a tendency in Foucault and his adherents to treat shifts between ages, periods, epistemes or regimes of truth as clear and sharp (and often incommensurable and inexplicable) by pointing out that these shifts often overlap, intertwine and entail reworkings of old ideas and practices.

The second and third chapters focus on possibilities for critique and alternatives in the form of self-formation. Since both teachers and learners are products of power relations, there is no neutral or distant standpoint from which one can criticise the present, and hence it is not a matter of asserting a better alternative and there is no oppressed but naturally free subject awaiting liberation. "Freedom is not an endpoint or set of principles, it is a state of being or mode of life" (50), and as a result, it is suggested, "freedom concerns the will to exercise power differently" (40).

The book also explores the possibility that education as a set of relations is not completely exhausted and limited by the school as institution and as a site of domination, but that other kinds of educational spaces could be created (and in this regard Ball makes several references to the anti-institutional, "deschooling" work of Foucault's contemporary, Ivan Illich - they were born in the same year, 1926).

Another insight worth taking further is Roman Stoic philosopher Seneca's aphorism, "men learn while they teach," cited by Foucault. Ball enlists this to suggest that schools as communities, both teachers and learners, must not only collectively define their own questions but also seek to answer them, by nurturing truth-telling (or parrhesia). The idea of learning while one teaches is full of possibilities for rethinking pedagogical relationships or "games of truth" (where some - not always the same people - deemed to know more than others are thereby authorised to direct, manage and teach these others) which avoid lapsing into one-sided, irreversible relationships of domination.

Building on Seneca, those learning while they teach no doubt would endeavour to learn during the teaching process, as they teach, as well as from the process itself; they 
might even learn in the same way that they teach; but above all their teaching should be a learning in itself, a care for self, a work of self on self and an exercise of liberty. And as an equally long and ancient tradition has it (stretching back at least as far as Cicero, but attributed to Solon, and repeated regularly thereafter up to Foucault), in order to take on the responsibility of managing and teaching others, one must first have learnt how to manage oneself, which in part may require being managed by another. Among the various possible implications of all this is that those who wish to learn, should teach; indeed, perhaps the ranks of educators should be confined to those who wish to learn, rather than those who have (or believe they have) knowledge to impart. A future age might even relinquish teaching teachers to teach, in favour of letting learners learn.

If the book has a shortcoming it lies in the "fast and easy" editing of the text. Dozens of spelling, grammatical and typographical errors clearly escaped the attention of proofreaders and automatic spellcheckers alike. To criticise these errors reflects no doubt as much on this reviewer's predilections and prior education as it does on the editing process. But perhaps it is also fitting that a book of this sort-which questions the varying "methods of correct training" to which learners and teachers have been subjected over the past few hundred years - contains so many little transgressions.

The existence of these technical shortcomings reminds us, too, that, for all their current emphasis on science, performance, measurement and development, schools have always been moralising institutions in which teachers constitute a pastorate. The fact that some teachers might wish to debate the significance of these errors, while others would consider them not even worth mentioning, shows how deeply immersed in systems of power and knowledge we all remain. In thus shedding more light on the limits of that which has made us what we are, Foucault as Educator invites us to reflect once again on Nietzsche's fear, echoed by Foucault, that "we are not getting rid of God because we still believe in grammar." 